\title{
ABOUT ENGINEERING AND GEOLOGICAL SURVEYS OF SOIL PROPERTIES IN THE CONSTRUCTION OF APARTMENT BUILDINGS
}

\author{
Ekaterina Lipatova $^{1}$ \\ Daniil Basik ${ }^{2}$ \\ Katerina Petrova ${ }^{3}$ \\ Ekaterina Makeeva ${ }^{4}$ \\ Natalia Sergeevna Gorelysheva ${ }^{5}$ \\ Denis Alecksandrovich Seroshtan ${ }^{6}$ \\ Elizaveta Viktorovna Goncharova ${ }^{7}$
}

\begin{abstract}
Engineering and geological surveys are summative concepts, the essence of which is to conduct a study of the geological properties of the soil on the territory of the construction site. The main goal is to obtain all the necessary materials to fully justify the possibility of designing and building any object on the selected territory. This study describes
\end{abstract} engineering and geological surveys of soil properties for the preparation of project documentation for the construction of an apartment building at the address Kirov region, Vyatskopolyansky district, village. Krasnaya Polyana, Druzhba str., 1. Statistical processing of physical characteristics of the studied soils, as

\footnotetext{
${ }^{1}$ Moscow State University Of Civil Engineering, Russia, Moscow, email: info@ores.su, https://orcid.org/0000-0002-9842-2847

2 Moscow State University Of Civil Engineering, Russia, Moscow, email: russia@prescopus.com, https://orcid.org/0000-0003-2103-3541

3 Moscow State University Of Civil Engineering, Russia, Moscow, email: editor@ores.su, https://orcid.org/0000-0001-5230-7897

${ }^{4}$ Moscow State University Of Civil Engineering, Russia, Moscow, email: global@ores.su, https://orcid.org/0000-0003-4177-374X

5 Moscow State University Of Civil Engineering, Russia, Moscow, email: global@ores.su, https://orcid.org/0000-0002-5663-7006

6 Moscow State University Of Civil Engineering, Russia, Moscow, email: russia@prescopus.com, https://orcid.org/0000-0001-5732-2690

7 Moscow State University Of Civil Engineering, Russia, Moscow, email: info@ores.su, https://orcid.org/0000-0001-7709-2511
} 
well as indicators of physical and mechanical properties of soils are presented.

Keywords: laboratory engineering and geological surveys, project documentation, soil properties, physical characteristics, statistical processing, reconnaissance survey, drilling, soil sampling, sounding, field stage, laboratory stage, Desk processing.

Engineering and geological surveys are a group of studies aimed at determining the geological and hydrogeological conditions in the area, intended for the future construction of a private house, apartment building, business object, linear highways, communication networks and any other capital structures [5].

The primary task of engineering and geological surveys is to determine the properties of the soil to select the configuration of the foundation-the basis of the future structure. Depending on the strength of the soil base, its corrosion activity, the depth of freezing, as well as the nature of underground water and its chemical composition, the type and depth of the foundation is determined, and the need for additional measures for protection and strength.

Engineering and geological surveys include several stages, the implementation of which is prescribed by the SNiP standards. The work includes [1]:

1. Preparation. Reconnaissance of the area, topographical research, study of archival materials on the site, determining the scope of upcoming work and the choice of methods.

2. The field phase. Drilling operations, sounding and stamp testing of soils, description of the geological and lithological structure of the soil section, sampling of soil samples and groundwater.

3. The laboratory stage. It is carried out in parallel with field work. In a certified chemical-soil laboratory, soil studies are conducted for physical and mechanical parameters: plasticity, fluidity, resistance to precipitation, capillarity, chemical composition

and degree of corrosion aggressiveness are determined.

4. The Desk phase. Processing of the data obtained using computer programs and mathematical calculations, drawing up a description of geological conditions, forecasting possible changes 
and the risk of dangerous natural processes, making a Technical report.

The object of this study is the properties of soils in the construction of multi-apartment residential buildings.

The purpose of this study is to conduct laboratory engineering and geological surveys of soil properties for the preparation of project documentation for the construction of an apartment building at the address: Kirov region,
Vyatskopolyansky district, village. Krasnaya Polyana, Druzhba str., 1.

So, let's imagine the composition and scope of work for engineering and geological surveys of soil properties during the construction of an apartment building at the address Kirov region, Vyatskopolyansky district, village. Krasnaya Polyana, Druzhby str., 1. in the form of table 1.

Table 1.Composition and scope of work

\begin{tabular}{|l|l|l|l|l|}
\hline № & Name of works & \multicolumn{1}{|l|}{$\begin{array}{l}\text { Unit } \\
\text { measurement }\end{array}$} & Quantity & \multirow{2}{*}{ Note } \\
\hline \multicolumn{2}{|l|}{ Field work } & Corrected during work \\
\hline 1 & Reconnoitering examination & $\mathrm{km}^{2}$ & 0,2 & \\
\hline 2 & Soil sampling & Sample & 20 & Corrected during work \\
\hline Laboratory works & $\begin{array}{l}\text { Determination of physical } \\
\text { properties of soil }\end{array}$ & Determ. & 20 & \\
\hline 3 & $\begin{array}{l}\text { Cameral treatment of the } \\
\text { laboratory data }\end{array}$ & Sample & 20 & Corrected during work \\
\hline 4
\end{tabular}

\section{PROPOSED METHODOLOGY}

To accomplish the tasks, a set of semi-laboratory and laboratory tests will be carried out to obtain data recording the state and physical properties of soils, identifying dangerous geological and engineering-geological processes.
Administratively, the site is located in the western part of the urbantype settlement Krasnaya Polyana of the Vyatskopolian district of the Kirov region in a residential building. The city of Vyatskiye Polyany, with the same name as the railway station, is located on the Moscow-Yekaterinburg railway. It is 
a regional center and it is located $18 \mathrm{~km}$ from the village Krasnaya Polyana. The distance from the city to the regional center (Kirov) is: $588 \mathrm{~km}$ by railway and $332 \mathrm{~km}$ by motorway . Vyatskopoliansky district is located in the southeastern part of the Kirov region and borders: in the northwest with the Malmyzhsky district, north and east with the Republic of Udmurtia; in the south and west with the Republic of Tatarstan.

The location of the area being examined is shown in the diagram of the area of work (Fig. 1).

Figure 1 - Location of the area being examined

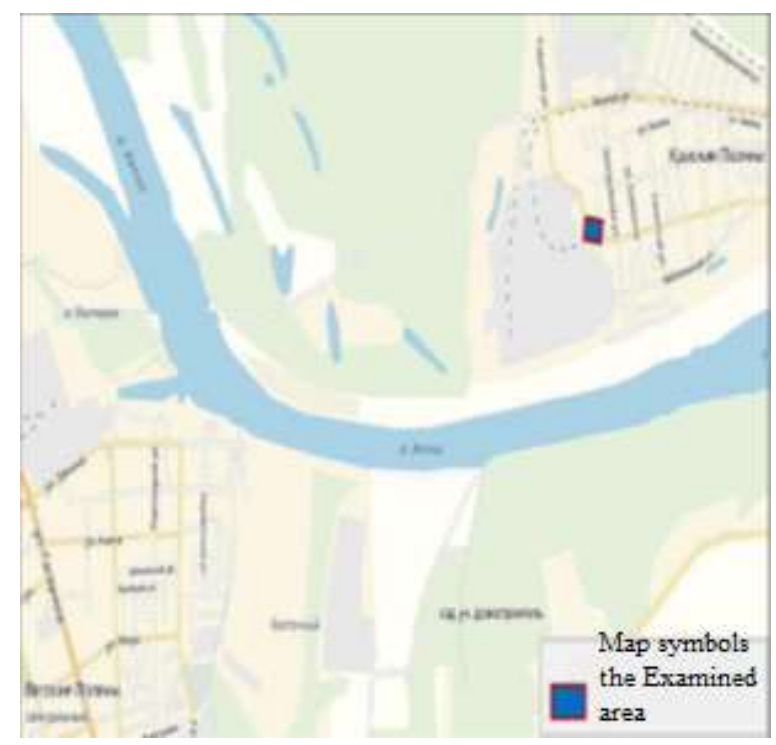

The field work was completed in May 2019. The breakdown and planned - high-altitude snapping of wells were done instrumentally. The catalogue of coordinates and waypoints of engineering and geological workings for the studied object is presented in table 1 . Coordinate system - MSC-43

Baltic altitude system

Table 1.Catalogue of coordinates and elevations of engineering and geological workings for the object

\begin{tabular}{|l|l|l|l|}
\hline \multirow{2}{*}{ № workings } & \multicolumn{2}{|l|}{ Coordinates } & Waypoints M \\
\cline { 2 - 3 } & $\mathrm{X}$ & Y & \\
\hline Well $1 \backslash$ & 320958,45 & 2286538,29 & 65,38 \\
\hline
\end{tabular}




\begin{tabular}{|l|l|l|l|}
\hline тсз.1 & & & \\
\hline Well 2\ тс3.2 & 320974,30 & 2286510,86 & 65,38 \\
\hline
\end{tabular}

The testing of the physical characteristics of soils was performed in the soil laboratory of VyatTISIz LLC in Kirov.

In order to conduct laboratory test in accordance with the applicable regulatory documents, the following set of engineering and geological works were carried out in the examined area:

- reconnoitering examination;

- drilling of the wells;

- soil sampling;

$$
\text { hydrogeological }
$$

examinations;

- static sounding;

- laboratory works;

- cameral processing.

Reconnoitering examination (engineering-geological) of the area was carried out according to SP 47.13330.2012 [10] and SP 11-105-97 [11] (part I, paragraph 5.4) in order to visually assess the nature of the relief, identify surface manifestations of modern geological and engineering geological processes that can adversely affect the stability of the designed structure, the assessment of possible changes in the geological environment under the influence of the construction and operation of structures [13-17].

Well drilling was carried out by a drilling rig PBU 2-312 core drill with a diameter of $198 \mathrm{~mm}$, using a drilling soil carrier. During the field period, 2 wells were drilled with a depth of $8.0 \mathrm{~m}$.

The selection of monoliths and samples, their packaging and transportation were carried out in accordance with GOST 12071-2014. In the process of drilling, a log of geological documentation of wells was kept.

After the completion of work, all workings were eliminated by backfilling them with excavated soil.

Static sounding was carried out in the circuit of the structure near the drilled wells, in order to clarify the geological and lithological section, according to the requirements of GOST 19912-2012 [6] by the mounted attachment of Geotest OJSC (Yekaterinburg) to the PBU-2-312 drilling rig based on the vehicle KAMAZ according to the pressing load method 
843

according to GOST 19912-2012. Type of 10 tons, the probe indentation speed is probe was II.

The diameter of the probe base $1.0 \mathrm{~m} / \mathrm{min}$, the type of sounding is without stabilization. Data was recorded is $35.7 \mathrm{~mm}$, the probe base area is 10 $\mathrm{cm}^{2}$, the side surface area is $250 \mathrm{~cm}^{2}$. The through $0.1 \mathrm{~m}$ with a TEST-K2M type controller with a maximum scale of 250 maximum efforts of the probe divisions.

indentation as a whole are not less than

Table 2.Statistical processing of the physical characteristics of soils (IGE-2 Super hard $(\alpha 1$ III $)$

\begin{tabular}{|c|c|c|c|c|c|c|c|c|c|c|c|c|c|}
\hline \multirow[b]{2}{*}{ 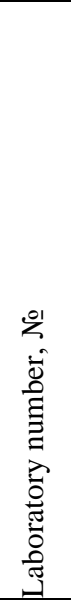 } & \multirow[b]{2}{*}{ 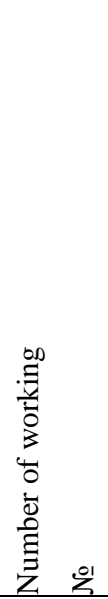 } & \multicolumn{2}{|c|}{$\begin{array}{l}\text { Sampling } \\
\text { depth }\end{array}$} & \multicolumn{3}{|c|}{ Density g / cm3 } & \multirow[b]{2}{*}{ 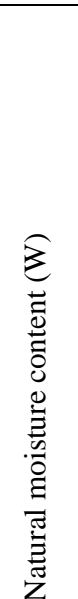 } & \multirow[b]{2}{*}{ 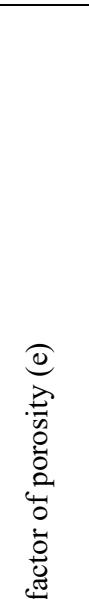 } & \multirow[b]{2}{*}{ 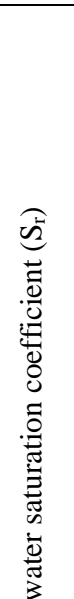 } & \multicolumn{2}{|c|}{$\begin{array}{l}\text { Humidity at } \\
\text { the border }\end{array}$} & \multirow[b]{2}{*}{ 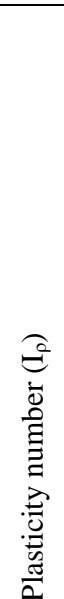 } & \multirow[b]{2}{*}{ 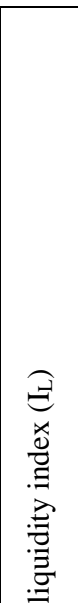 } \\
\hline & & from & till & 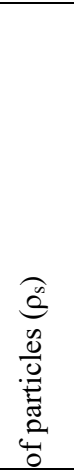 & 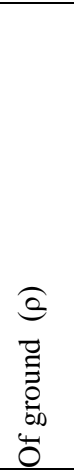 & 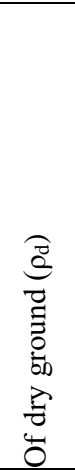 & & & & 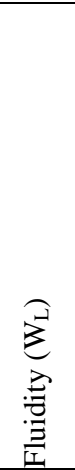 & 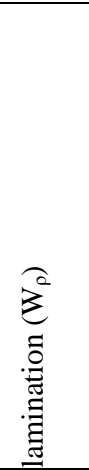 & & \\
\hline 541 & 1 & 1,2 & 1,4 & 2,69 & 1,92 & 1,66 & 15,7 & 0,921 & 0,68 & 23,6 & 17,6 & 6,0 & $\begin{array}{l}- \\
0,32\end{array}$ \\
\hline 542 & 1 & 1,6 & 1,8 & 2,69 & 1,95 & 1,64 & 17,8 & 0,642 & 0,75 & 22,6 & 17,7 & 4,9 & 0,02 \\
\hline 543 & 1 & 2,0 & 2,2 & 2,69 & 1,96 & 1,64 & 19,7 & 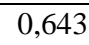 & 0,82 & 24,2 & 19,5 & 4,7 & 0,04 \\
\hline 544 & 1 & 2,4 & 2,6 & 2,69 & 1,92 & 1,62 & 18,7 & \begin{tabular}{|l|l|}
0,663 \\
\end{tabular} & 0,76 & 24,1 & 18,6 & 5,5 & 0,02 \\
\hline 645 & 1 & 2,9 & 3,1 & 2,69 & 1,95 & 1,62 & 20,1 & \begin{tabular}{|l|l|}
0,657 \\
\end{tabular} & 0,82 & 24,6 & 19,7 & 4,9 & 0,08 \\
\hline 652 & 2 & 0,8 & 1,0 & 2,69 & 1,94 & 1,67 & 16,5 & 0,615 & 0,72 & 22,2 & 16,7 & 5,5 & $\begin{array}{l}- \\
0,04\end{array}$ \\
\hline 653 & 2 & 1,4 & 1,6 & 2,69 & 1,94 & 1,68 & 15,6 & \begin{tabular}{|l|l}
0,613 \\
\end{tabular} & 0,70 & 21,1 & 15,6 & 5,5 & 0,00 \\
\hline 654 & 2 & 2,0 & 2,2 & 2,69 & 1,85 & 1,59 & 16,5 & 0,691 & 0,63 & 22,9 & 16,2 & 6,7 & 0,02 \\
\hline 655 & 2 & 2,6 & 2,8 & 2,69 & 1,88 & 1,61 & 17,1 & 0,676 & 0,68 & 23,2 & 17,4 & 5,6 & $\begin{array}{l}- \\
0,05\end{array}$ \\
\hline 656 & 2 & 3,0 & 3,2 & 2,69 & 1,92 & 1,60 & 19,8 & 0,676 & 0,79 & 25,3 & 20,1 & 5,2 & $\begin{array}{l}- \\
0,06\end{array}$ \\
\hline
\end{tabular}


844

\begin{tabular}{|c|c|c|c|c|c|c|c|c|c|c|c|}
\hline Number of Definitions & $\mathrm{n}$ & 10 & 10 & 10 & 10 & 10 & 10 & 10 & 10 & 10 & 10 \\
\hline Min value & $\mathrm{Xmin}$ & 2,69 & 1,85 & 1,59 & 1,56 & 0,603 & 0,63 & 21,1 & 15,6 & 4,7 & $\begin{array}{l}- \\
0,32\end{array}$ \\
\hline Max. value & $\mathrm{X}_{\max }$ & 2,69 & 1,96 & 1,68 & 20,1 & 0,691 & 0,82 & 25,3 & 20,1 & 6,7 & 0,08 \\
\hline Normative value & $X_{n}$ & 2,66 & 1,92 & 1,63 & 17,7 & 0,649 & 0,73 & 23,4 & 17,9 & 5,5 & $\begin{array}{l}- \\
0,03\end{array}$ \\
\hline Dispersion & & 0,000 & 0,001 & 0,001 & 3,038 & 0,001 & & 1,542 & 2,348 & & \\
\hline $\begin{array}{l}\text { Mean square } \\
\text { deviation }\end{array}$ & $\mathrm{S}$ & 0,000 & 0,033 & 0,029 & 1,743 & 0,029 & & 1,242 & 1,532 & & \\
\hline To variation & $\mathrm{V}$ & 0,00 & 0,02 & 0,02 & 0,10 & 0,05 & & 0,05 & 0,09 & & \\
\hline $\begin{array}{l}\text { The value of the } \\
\text { coefficient with a } \\
\text { confidence probability } \\
\text { of } \alpha=0.95\end{array}$ & $\mathrm{t}_{\alpha}$ & & 1,83 & & & & & & & & \\
\hline $\begin{array}{l}\text { Accuracy indicator of } \\
\text { the average value }\end{array}$ & $\rho_{o}$ & & 0,010 & & & & & & & & \\
\hline To reliability & $\mathrm{Y}_{\mathrm{g}}$ & & 1,010 & & & & & & & & \\
\hline $\begin{array}{l}\text { The calculated value of } \\
\text { the bearing capacity }\end{array}$ & $\mathrm{X}_{\mathrm{t}}$ & & 1,90 & & & & & & & & \\
\hline $\begin{array}{l}\text { The value of the } \\
\text { coefficient with a } \\
\text { confidence probability } \\
\text { of } \alpha=0,85\end{array}$ & $\mathrm{t}_{\alpha}$ & & 1,10 & & & & & & & & \\
\hline $\begin{array}{l}\text { Accuracy indicator of } \\
\text { the average value }\end{array}$ & $\rho_{\mathrm{o}}$ & & 0,006 & & & & & & & & \\
\hline To reliability & $\mathrm{Yg}_{\mathrm{g}}$ & & 1,006 & & & & & & & & \\
\hline $\begin{array}{l}\text { The calculated value of } \\
\text { the strain }\end{array}$ & $\mathrm{X}_{\mathrm{I}}$ & & 1,91 & & & & & & & & \\
\hline
\end{tabular}

Laboratory tests were

GOST 5180-2015 "Soils.

performed to determine the nomenclature and physical characteristics of soils in accordance with:

\section{V. $01-\mathrm{N}^{\circ} 01-$ Ano $2020-$ Special Edition}

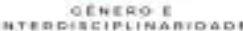


GOST 25100-2011 "Soils.

Classification"[4];

GOST 20522-2012 "Soils.

Methods of statistical processing of test results"[5].

Cameral processing. Based on the results of cameral processing of field and laboratory studies, the physic and mechanical properties of soils are determined with their display in text and tabular form.

Statistical processing of test results is performed in accordance with
GOST 20522-2012 "Soils. Methods of statistical processing of test results "(table 2, 3). To obtain the calculated values for the deformation and bearing capacity, we used the values of the coefficient t $\alpha$ with a one-sided confidence probability $\alpha$ equal to 0.85 and 0.95 with the number of degrees of freedom indicated in Table E. 2 GOST 20522-2012 "Methods of statistical processing of test results".

Table 3.Statistical processing of the physical characteristics of soils (IGE-3 Soft sandy loam ( $\alpha 2$ III).

\begin{tabular}{|c|c|c|c|c|c|c|c|c|c|c|c|c|c|}
\hline \multirow[b]{2}{*}{ 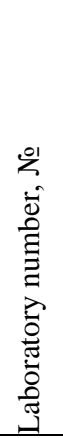 } & \multirow[b]{2}{*}{ 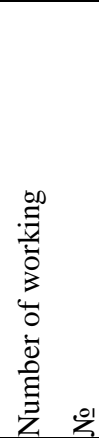 } & \multicolumn{2}{|c|}{$\begin{array}{l}\text { Sampling } \\
\text { depth }\end{array}$} & \multicolumn{3}{|c|}{ Density g / cm3 } & \multirow[b]{2}{*}{ 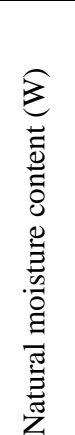 } & \multirow[b]{2}{*}{ 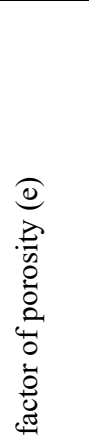 } & \multirow[b]{2}{*}{ 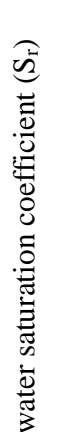 } & \multicolumn{2}{|c|}{$\begin{array}{l}\text { Humidity at } \\
\text { the border }\end{array}$} & \multirow[b]{2}{*}{ 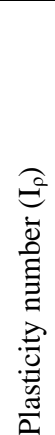 } & \multirow[b]{2}{*}{ 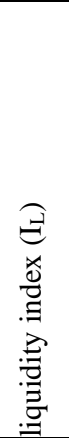 } \\
\hline & & from & till & 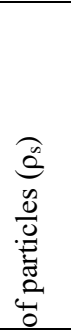 & $\begin{array}{l}\widehat{\Theta} \\
\vec{\Xi} \\
\vdots \\
0 \\
0 \\
0 \\
0\end{array}$ & 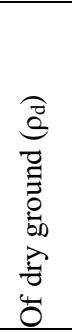 & & & & 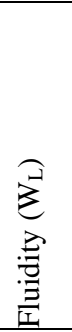 & 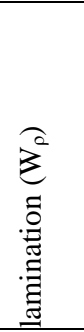 & & \\
\hline 646 & 1 & 4,0 & 4,2 & 2,69 & 1,99 & 1,63 & 21,9 & 0,648 & 0,91 & 24,2 & $\overline{17,9}$ & 6,3 & 0,64 \\
\hline 647 & 1 & 4,9 & 5,1 & 2,69 & 1,85 & 1,59 & 22,4 & 0,688 & 0,88 & 25,3 & 18,6 & 6,7 & 0,57 \\
\hline 648 & 1 & 6,1 & 6,6 & 2,69 & 1,95 & 1,59 & 22,7 & 0,693 & 0,88 & 25,6 & 20,1 & 5,5 & 0,47 \\
\hline 649 & 1 & 7,6 & 7,8 & 2,69 & 1,97 & 1,62 & 22,0 & 0,666 & 0,89 & 25,1 & 18,3 & 6,8 & 0,54 \\
\hline 650 & 1 & 7,8 & 8,0 & 2,69 & 1,97 & 1,67 & 17,9 & 0,610 & 0,79 & 21,7 & 16,2 & 5,5 & 0,31 \\
\hline 657 & 2 & 4,0 & 4,2 & 2,69 & 1,96 & 1,61 & 21,5 & 0,668 & 0,87 & 24,6 & 24,6 & 6,5 & 0,52 \\
\hline 658 & 2 & 5,2 & 5,4 & 2,69 & 2,01 & 1,68 & 19,4 & 0,601 & 0,87 & 22,2 & 22,2 & 5,9 & 0,53 \\
\hline 659 & 2 & 6,2 & 6,4 & 2,69 & 1,94 & 1,66 & 17,2 & 0,625 & 0,74 & 20,8 & 20,8 & 5,5 & 0,35 \\
\hline 660 & 2 & 7,9 & 7,5 & 2,69 & 2,06 & 1,74 & 18,0 & 0,546 & 0,89 & 21,8 & 21,8 & 6,7 & 0,49 \\
\hline 661 & 2 & 7,8 & 8,0 & 2,69 & 1,95 & 1,65 & 18,5 & 0,635 & 0,78 & 22,5 & 22,5 & 6,5 & 0,39 \\
\hline \multicolumn{3}{|c|}{ Number of Definitions } & $\mathrm{n}$ & 10 & 10 & 10 & 10 & 10 & 10 & 10 & 10 & 10 & 10 \\
\hline
\end{tabular}


846

\begin{tabular}{|c|c|c|c|c|c|c|c|c|c|c|c|}
\hline Min value & Xmin & 2,69 & 1,94 & 1,59 & 17,2 & 0,546 & 0,74 & 20,8 & 15,1 & 5,5 & 0,31 \\
\hline Max. value & $\mathrm{X}_{\max }$ & 2,69 & 2,06 & 1,74 & 22,7 & 0,693 & 0,91 & 25,6 & 20,1 & 6,8 & 0,64 \\
\hline Normative value & $X_{n}$ & 2,66 & 1,98 & 1,64 & 20,2 & 0,638 & 0,85 & 23,4 & 17,2 & 6,2 & 0,47 \\
\hline Dispersion & & 0,000 & 0,001 & 0,002 & 4,616 & 0,002 & & 3,097 & 2,683 & & \\
\hline Mean square deviation & $S$ & 0,000 & 0,037 & 0,046 & 2,149 & 0,045 & & 1,760 & 1,638 & & \\
\hline To variation & $\mathrm{V}$ & 0,00 & 0,02 & 0,03 & 0,11 & 0,07 & & 0,06 & 0,10 & & \\
\hline $\begin{array}{l}\text { The value of the } \\
\text { coefficient with a } \\
\text { confidence probability } \\
\text { of } \alpha=0.95\end{array}$ & $\mathrm{t}_{\alpha}$ & & 1,83 & & & & & & & & \\
\hline $\begin{array}{l}\text { Accuracy indicator of } \\
\text { the average value }\end{array}$ & $\rho_{\mathrm{o}}$ & & 0,011 & & & & & & & & \\
\hline To reliability & $Y_{g}$ & & 1,011 & & & & & & & & \\
\hline $\begin{array}{l}\text { The calculated value of } \\
\text { the bearing capacity }\end{array}$ & $\mathrm{X}_{\mathrm{t}}$ & & 1,95 & & & & & & & & \\
\hline $\begin{array}{l}\text { The value of the } \\
\text { coefficient with a } \\
\text { confidence probability } \\
\text { of } \alpha=0,85\end{array}$ & $\mathrm{t}_{\alpha}$ & & 1,10 & & & & & & & & \\
\hline $\begin{array}{l}\text { Accuracy indicator of } \\
\text { the average value }\end{array}$ & $\rho_{\mathrm{o}}$ & & 0,006 & & & & & & & & \\
\hline To reliability & $\mathrm{Yg}_{\mathrm{g}}$ & & 1,006 & & & & & & & & \\
\hline $\begin{array}{l}\text { The calculated value of } \\
\text { the strain }\end{array}$ & $\mathrm{X}_{\mathrm{I}}$ & & 1,96 & & & & & & & & \\
\hline
\end{tabular}

The standard values of the indicators of mechanical properties according to IGE-2, 3 are taken

\section{RESULTS}

The values of the indicators of according to table. B.2.3 adj. B SP 22.13330.2011 [9], the calculations are performed according to the clause 5.3.18, taking into account table 5.11 SP 22.13330.2011 physical and mechanical properties of soils are given in table 4 "Summary table of indicators of physical and mechanical properties of soils."

Table 4.Summary table of indicators of physical and mechanical properties of soils

\begin{tabular}{|l|l|l|}
\hline Name of indicator & soil unit 2 & soil unit 3 \\
\hline
\end{tabular}


847

\begin{tabular}{|c|c|c|c|}
\hline & & $\begin{array}{lll}\text { sandy } & \text { clay } & \left(\alpha_{1}\right. \\
\text { III }) & & \end{array}$ & $\begin{array}{l}\text { soft sandy loam } \\
\left(\alpha_{2} \text { III }\right) .\end{array}$ \\
\hline \multirow[t]{3}{*}{ Soil density } & $\rho_{\text {н }}$ & 1,92 & 1,98 \\
\hline & $\rho_{\text {I }}$ & 1,90 & 1,95 \\
\hline & $\rho_{\text {II }}$ & 1,91 & 1,96 \\
\hline Porosity factor & $\mathrm{e}$ & 0,649 & 0,638 \\
\hline Plasticity index, $\%$ & $\mathrm{I}_{\mathrm{p}}$ & 5,5 & 6,2 \\
\hline Liquidity index & $\mathrm{I}_{\mathrm{L}}$ & $-0,03$ & 0,47 \\
\hline \multirow[t]{3}{*}{ Specific cohesion (c), кkPa } & $\mathrm{C}_{\mathrm{H}}$ & 15 & 13 \\
\hline & $\mathrm{C}_{\mathrm{I}}$ & 10 & 9 \\
\hline & $\mathrm{C}_{\text {II }}$ & 15 & 13 \\
\hline \multirow[t]{3}{*}{ Angle of internal friction, degrees } & $\varphi_{\mathrm{H}}$ & 27 & 24 \\
\hline & $\varphi_{\mathrm{I}}$ & 23 & 21 \\
\hline & $\varphi_{\text {II }}$ & 27 & 24 \\
\hline Module of deformation, $\mathrm{MPa}$ & $\mathrm{E}$ & 16 & 17 \\
\hline Design resistance, $\mathrm{kPa}$ & $\mathrm{R}_{0}$ & 263 & 219 \\
\hline K-ratio & $\mathrm{k}$ & 1,1 & 1,1 \\
\hline
\end{tabular}

$\rho I$ is the calculated indicator for calculations of bearing capacity (with confidence probability $\alpha=0.95$ );

$\rho I I$ is the calculated indicator for calculations by deformation (at a confidence level of $\alpha=0.85$ );

K - The coefficient adopted when calculating the resistance of the soil of the base, determined by the formula (5.7) SR 22.13330.2011.

\section{CONCLUSION}

Thus, we conclude on the basis of laboratory tests. The work site is located in the western part of the urban- type village of Krasnaya Polyana, Vyatskopolian district, Kirov region. Residential and public buildings are located in the immediate vicinity of the examination site. At the time of the examination, the proposed construction site is free from development and is a wasteland. In geomorphological terms, the site of work is confined to the second floodplain terrace of the river Vyatka. The territory of the examionation site has a general decrease in relief in a southerly direction towards $\mathrm{r}$. Vyatka with a slope of $0^{\circ} 30^{\prime}$, the surface of the site is planned (previously a residential 
building was located on the site). The absolute elevations of the workings on the site vary from 65.38 to $65.53 \mathrm{~m}$.

The upper quaternary alluvial deposits of the first floodplain terrace (a1III) and technogenic formations (t IV) are involved in the geological structure. In the section are highlighted (top to bottom):

Man-made soil (t IV):

Soil Unit-1 is a mechanical mixture of loam, sand, in the roof layer with small building debris.
Alluvial deposits (a2III):

Soil Unit-2 is sandy brown, hard sand, plastic interlayers;

Soil Unit-3 is brown, plastic sandy loam.

The groups of soils according to the difficulty of developing a singlebucket excavator according to GESN81-02-01-2017 [12] (Appendix 1.1) are shown in Table 5.

Table 5. Difficulty groups of soils IGE Soil

\begin{tabular}{|lccc|}
\hline & name & Category & Item number \\
\hline 1 Technogenic soil & 2 & $35 \mathrm{v}$ \\
\hline 2 Sandy loam, solid & 1 & $36 \mathrm{~b}$ & \\
\hline 3 Soft sandy loam & 1 & $36 \mathrm{~b}$ \\
\hline
\end{tabular}

\section{LIST OF REFERENCES}

"Urban Planning Code of the Russian Federation" dated December 29, 2004 N 190-FL (as amended on August 2, 2019) (as amended and supplemented, entered into force on August 13, 2019) // “Rossiyskaya Gazeta”, No. 290 $12 / 30 / 2004$

GOST 30416-96 Soils. Laboratory tests. General Provisions // Tekhekspert
GOST 5180-84 Soils. Methods of laboratory determination of physical characteristics // "Tekhekspert"

GOST 25100-2011 "Soils. Classification "// ATP" Tekhekspert " GOST 20522-2012 "Soils. Methods of statistical processing of test results "// "Tekhekspert"

"GOST 19912-2012. Interstate standard. Soils. Methods of field tests by static and 
dynamic sounding "(entered into force by the Order of Rosstandart dated December 27, 2012 N 2005-ст) (as amended on April 18, 2019) //“Tekhekspert"

"SR 47.13330.2016. Set of rules. Engineering examinations for construction. The main provisions. Updated edition of SNiP 11-02-96 "(approved and put into effect by the Order of the Ministry of Construction of Russia dated 12.30.2016 N 1033 / pr) // "Tekhekspert" "SR 317.1325800.2017. Set of rules. Geodetic engineering examinations for construction. General rules for the production of works "(approved and put into effect by Order of the Ministry of Construction of Russia dated December 22, 2017 N 1702 / pr) // “Tekhekspert” "SR 22.13330.2011. Set of rules. Foundations of buildings and structures. Updated version of SNiP 2.02.01-83* "(approved by Order of the Ministry of Regional Development of the Russian Federation of December 28, 2010 N 823) // " Tekhekspert "

“SR 47.13330.2012. Set of rules. Engineering examinations for construction. The main provisions. The updated edition of SNiP 11-02-96 "(approved by the Order of the Gosstroy of Russia dated 10.12.2012 N 83 / GS) // Tekhekspert

"SR 11-105-97. Engineering and geological examinations for construction. Part I. General rules for the performance of work "(approved by the Letter of the Gosstroy of Russia of 10/14/1997 N 9-4 / 116) // "Tekhekspert "

State itemized cost estimate standards 81-02-01-2017. State estimated standards. State estimated norms. State elemental estimated norms for construction and special construction works. Collection 1. Earthwork "(approved and introduced by Order of the Ministry of Construction of Russia dated 12.30.2016 N 1038 / pr) // “ Tekhekspert"

Rahman, P. A., Panchenko, A. A., \& Safarov, A. M. (2017). Using neural networks for prediction of air pollution index in industrial city. IOP Conference Series: Earth and Environmental Science, 87(4).

https://doi.org/10.1088/1755$\underline{1315 / 87 / 4 / 042016}$

Avdeev, Y. M., Gorovoy, S. A., Karpenko, E., Kudryavtsev, V., \& Kozlovsky, L. (2020). Evaluation of the state of green plants under the conditions of urbanization. [Avaliação do estado 
das plantas verdes sob as condições de urbanização] Periodico Tche Quimica, 17(34), 966-975.

Yemelyanov, V., Tochilkina, T., Vasilieva, E., Nedelkin, A., \& Shved, E. (2018). Computer diagnostics of the torpedo ladle cars. Paper presented at the AIP Conference Proceedings, 2034 doi:10.1063/1.5067351

Rahman, P. A. (2018). Analysis of stationary availability factor of two-level backbone computer networks with arbitrary topology. Journal of Physics: Conference Series, 1015(2). https://doi.org/10.1088/1742$\underline{6596 / 1015 / 2 / 022016}$

Yemelyanov, V. A., Yemelyanova, N. Y., Nedelkin, A. A., \& Zarudnaya, M. V. (2018). Neural network to diagnose lining condition. Paper presented at the IOP Conference Series: Materials Science and Engineering, , 327(2) doi:10.1088/1757-899X/327/2/022107 